\title{
Water masses in Kangerlussuaq, a large fjord in West Greenland: the processes of formation and the associated foraminiferal fauna
}

\author{
Morten Holtegaard Nielsen, ${ }^{1}$ Dorthe Reng Erbs-Hansen ${ }^{2}$ \& Karen Luise Knudsen ${ }^{2}$ \\ 1 Arctic Technology Centre, Department of Civil Engineering, Technical University of Denmark, Building 204, Kemitorvet, DK-2800 Kgs. Lyngby, \\ Denmark \\ 2 Department of Earth Sciences, University of Aarhus, Høegh-Guldbergs Gade 2, DK-8000 Århus C, Denmark
}

\author{
Keywords \\ Arctic fjord; dense water formation; \\ foraminiferal distribution; mixing; water \\ masses. \\ Correspondence \\ Morten Holtegaard Nielsen, Arctic \\ Technology Centre, Department of Civil \\ Engineering, Technical University of Denmark, \\ Building 204, Kemitorvet, DK-2800 Kgs. \\ Lyngby, Denmark. E-mail: mhn@byg.dtu.dk
}

doi:10.1111/j.1751-8369.2010.00147.x

\begin{abstract}
The water masses in Kangerlussuaq (Søndre Strømfjord) in West Greenland were studied during both a summer and a winter field survey. In order to obtain an improved understanding of the relationship between the physical oceanography and modern foraminiferal assemblage distributions, conductivity-temperature-density measurements were carried out in connection with sediment surface sampling along a transect through the $180 \mathrm{~km}$ long fjord. The exchange between the inner part of Kangerlussuaq $(275 \mathrm{~m}$ deep) and the ocean is restricted by an almost $100 \mathrm{~km}$ long outer, shallow part. Our study shows that the water mass in this inner part is almost decoupled from the open ocean, and that in winter the inner part of the fjord is ice covered and convection occurs as a result of brine release. These processes are reflected in the foraminiferal assemblage, which consists of a sparse agglutinated fauna, indicative of carbonate dissolution. A monospecific, calcareous assemblage (Elphidium excavatum forma clavata) occurs in the innermost, shallow part, which is strongly influenced by sediment-loaded meltwater during the summer. The outer, shallow part of the fjord is dominated by strong tidal mixing, and in summer the density of the incoming water does not exceed the bottom water density in the inner fjord. The foraminiferal assemblage here reflects high bottom water current velocity and an influence of water with relatively high salinity. Kangerlussuaq can be regarded as a modern analogue for ice-proximal environments in the Quaternary, with a strong seasonal forcing caused by freshwater run-off and sea-ice formation.
\end{abstract}

Generally, there is a close relationship between the watermass characteristics at the sea floor and the distribution of different species and species groups of benthic foraminifera (e.g., Murray 1991, 2006). As foraminiferal tests are usually well preserved in fossil sedimentary records, they are extremely useful in palaeoenvironmental studies.

The aim of this paper is to present for the first time new data coupling water-mass characteristics, measured with a conductivity-temperature-density (CTD) probe in Kangerlussuaq (Søndre Strømfjord), West Greenland (Fig. 1), with the distribution of recent foraminifera in the area. This is the basis for an improved understanding of the dynamics of a large fjord, which is strongly influ- enced by both meltwater and tide water, in relation to the characteristics of the modern foraminiferal community. In addition, the results from Kangerlussuaq will contribute to future palaeoceanographic and climatic studies in the same area, as well as to Quaternary palaeoenvironmental studies in general.

A number of investigations of modern foraminiferal distributions in the Arctic have been carried out in shelf and fjord areas, for instance, in the eastern Canadian Arctic (e.g., Vilks 1969, 1989; Scott et al. 1980; Mudie et al. 1983) and in the northern North Atlantic, as well as in the Russian Arctic (e.g., Hansen \& Knudsen 1992, 1995; Hald et al. 1994; Hald \& Steinsund 1996). Mostly, 

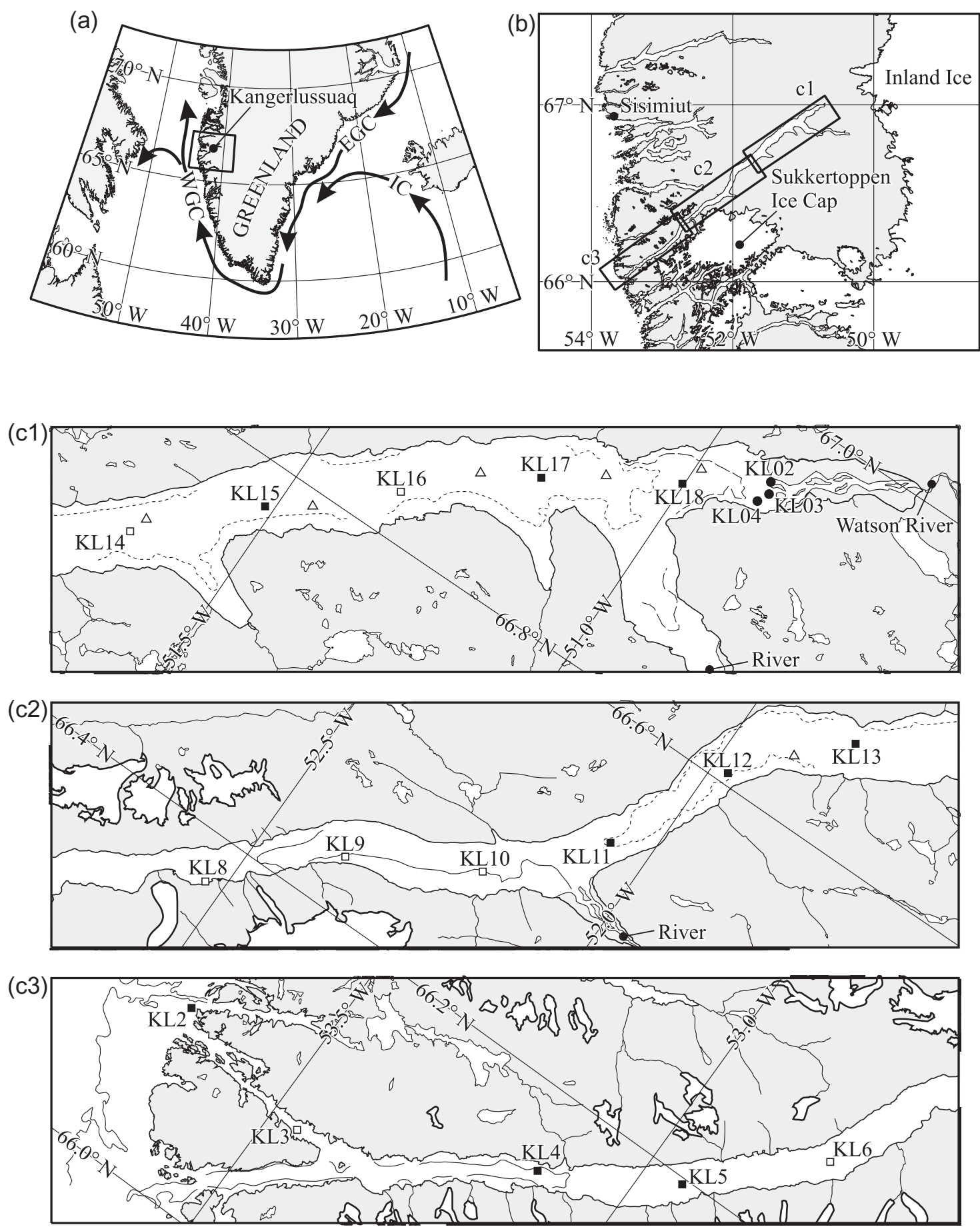

Fig. 1 Maps of Kangerlussuaq showing sampling locations and rough bathymetry. (a) The regional surface currents: West Greenland Current (WGC); East Greenland Current (EGC); Irminger Current (IC). (b) Location of Kangerlussuaq between the inland ice and the ocean. (c1-c3) Detailed sections of Kangerlussuaq: locations of conductivity-temperature-density (CTD) profiles and HAPS samples from August 2005 (ロ); CTD profiles from August 2005 $(\square)$; Van Veen samples from August 2005 (@); CTD profiles from February $2006(\triangle)$. The depth contours are $50 \mathrm{~m}$ (solid line), $100 \mathrm{~m}$ (long-dashed line) and $200 \mathrm{~m}$ (short-dashed line). The locations of the three major rivers, including the Watson River, are shown. 
these studies refer to previously published oceanographic data, which may, as also stated by Polyak et al. (2002), lead to inaccurate results, particularly near strong horizontal or vertical gradients in the properties of the water masses.

A few studies of modern foraminiferal distributions have been carried out in direct connection with measurements of water-mass properties in Spitsbergen and northern Norway (e.g., Hald \& Korsun 1997; Korsun \& Hald 1998, 2000; Husum \& Hald 2004) or even with CTD measurements, as in Greenland fjord and shelf areas (Jennings \& Helgadóttir 1994; Madsen \& Knudsen 1994; Lloyd 2006a). There is a need for an expansion of this kind of study in Greenland in order to establish an improved basis for the understanding of palaeoclimatic changes in the area. Greenland has potentially a number of modern analogue areas for the specific marine environments that prevailed in larger parts of the Northern Hemisphere during the Quaternary glacial periods. Particularly important are the many fjords with direct contact to calving glaciers and estuaries with large quantities of meltwater entering from the inland ice.

Examples of palaeoenvironmental studies based on fossil benthic foraminiferal assemblages from West and East Greenland shelf and fjord areas are described by Jennings \& Weiner (1996), Dowdeswell et al. (2000), Lassen et al. (2004), Lloyd et al. (2005), Lloyd (2006b) and Møller et al. (2006). Palaeoclimatic interpretations of glacial and interglacial records from onshore sites in North, West and East Greenland have been presented by, e.g., Feyling-Hanssen (1990), Feyling-Hanssen \& Funder (1990), Bennike et al. (1994), Vosgerau et al. (1994) and Kelly et al. (1999).

\section{Physical and hydrographical setting}

Kangerlussuaq is a large fjord in West Greenland, located some $100 \mathrm{~km}$ to the south-east of Sisimiut (see Fig. 1). It is $180 \mathrm{~km}$ long and consists roughly of two parts: an inner part, which is relatively wide (about $4 \mathrm{~km}$ ) and deep (up to about $275 \mathrm{~m}$ ), and an outer part, which is relatively narrow (about $1 \mathrm{~km}$ ) and shallow (25-100 m). The outer, narrow and shallow part occupies approximately half of the fjord (ca. $100 \mathrm{~km}$ ), and because of its length, does not resemble a typical sill as found in many other Arctic fjords (e.g., Hald \& Korsun 1997; Korsun \& Hald 2000; Møller et al. 2006). The sediment cover is thin, if present, in the outer shallow part because of strong currents (see below).

The transition between the inner and outer part of the fjord is characterized by a steep slope, rising $230 \mathrm{~m}$ over a distance of $20 \mathrm{~km}$. This morphology presumably results from the hard Archadian bedrock complex, which is unaffected by later folding phases, occupying the outer part of the fjord (Henriksen et al. 2000). The inner part, however, was created during the Nagssugtoqidian folding phase, during which it was metamorphosed and folded into the older bedrock, which softened the bedrock somewhat, and made it less resistant to erosion (Henriksen et al. 2000). The inner fjord resembles a U-shaped basin: a gorge cut into the bedrock and filled with fine-grained sediments (observed on the echo sounder).

The oceanographic setting along the West Greenland coast (Fig. 1) is governed by the West Greenland Current (WGC), which is a mixture of the East Greenland Current (EGC) and the Irminger Current (IC) (e.g., Buch 2002). The EGC originates in the Arctic Ocean: it is cold and of relatively low salinity. The IC is a branch of the North Atlantic Current, which is relatively warm and of relatively high salinity. They join at Kap Farvel and continue towards north as the WGC (Andersen 1981). The EGC component of the WGC dominates the coastal and upper part of the water column along the West Greenland coast, until it turns westward around $65-66^{\circ} \mathrm{N}$, whereas the IC component dominates below the EGC component of the WGC and further westwards (Andersen 1981; Buch 2000, 2002). Mixing between the two components (EGC and IC) takes place, and, as the WGC continues northwards from 65 to $66^{\circ} \mathrm{N}$, it consists mainly of Atlantic Water, which is further transformed by mixing with meltwater run-off and iceberg calving along the West Greenland coast.

The fjord is subject to tides with a range of $2-4 \mathrm{~m}$. The tides generate flow speeds of up to several metres per second through the narrow, shallow outer part of the fjord. In the summertime, the fjord receives large quantities of freshwater from mainly three rivers that drain meltwater from the inland ice and the smaller Sukkertoppen Ice Cap, located to the south of the fjord (Fig. 1). Watson River, the larger of these rivers, flows into Kangerlussuaq at the innermost point of the fjord (Fig. 1). The freshwater input to the fjord is much influenced by the meteorological conditions, and it usually peaks in late July or early August. In 2005, the peak flow in Watson River exceeded $1000 \mathrm{~m}^{3} \mathrm{~s}^{-1}$ (Hasholt, pers. comm.). From late October to early May the flow in Watson River is close to zero (Tinghuus, pers. comm.).

Additionally, the rivers carry large quantities of finegrained sediment, which leads to high sedimentation rates in the fjord (data not shown). At the beginning of November, sea ice starts to form in the inner part of the fjord, eventually reaching a thickness of about $1 \mathrm{~m}$. In the outer, shallow part the tidal currents are too strong for ice to form. In the middle of June the ice cover breaks up (Tinghuus, pers. comm.). 


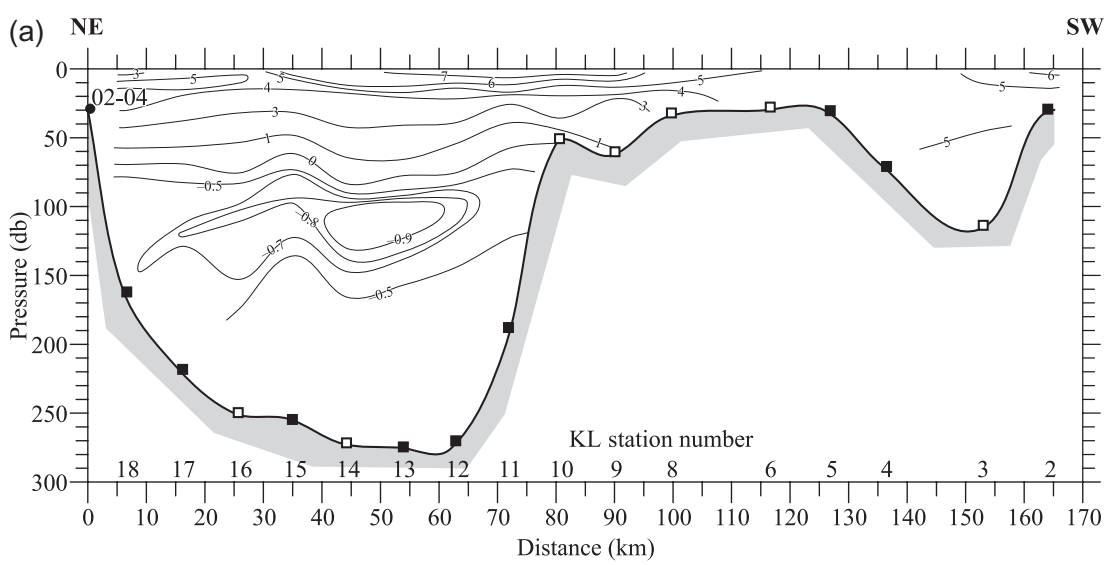

(b)

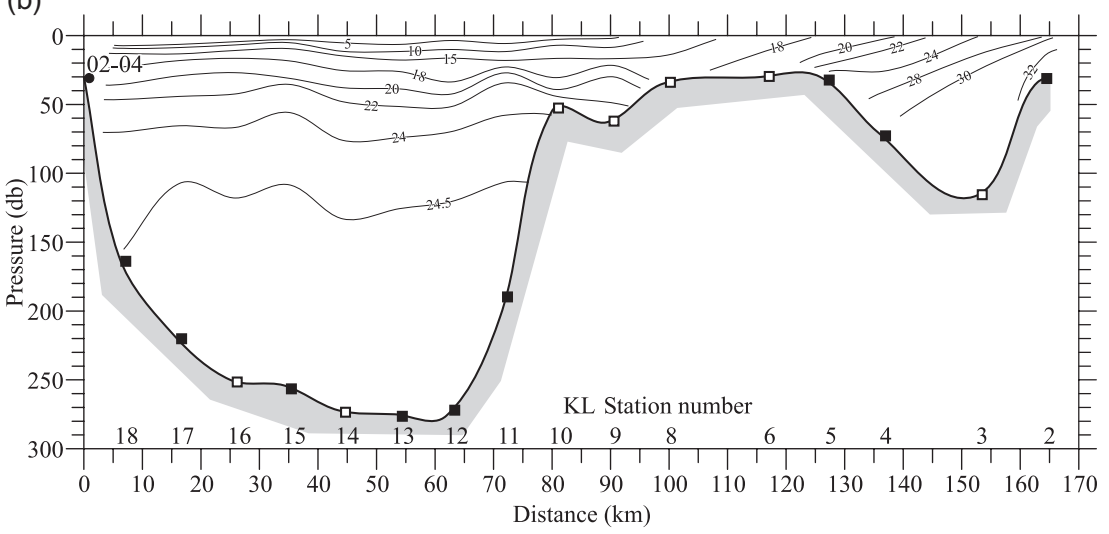

Fig. 2 Along-fjord distribution of (a) potential temperature and (b) salinity, measured on 3 and 4 August $2005(1 \mathrm{db}=\mathrm{ca} .1 \mathrm{~m})$. The values at the isolines are as indicated. The locations of the sampling sites are shown and marked as in Fig. 1. Note the direction of the plot (from north-east to south-west).

\section{Materials and methods}

Two surveys were carried out on Kangerlussuaq, on 3-5 August 2005 and 26-27 February 2006. The first was carried out from a small ship, whereas the second took place using a snowmobile on the ice-covered, inner part of the fjord.

A total of 16 stations were visited on the August cruise (Fig. 1). At each station, we made vertical profiles of in situ conductivity and temperature using a 19plus SEACAT Profiler (Sea-Bird Electronics, Bellevue, WA, USA). Data were recorded at $4 \mathrm{~Hz}$, the instrument was lowered at a speed of up to $0.5 \mathrm{~m} \mathrm{~s}^{-1}$ and the profiles were continued until the instrument touched the bottom. From the observations of conductivity, temperature and pressure, standard software was used to calculate salinity, potential temperature and potential density (all dimensionless; UNESCO 1981) (Figs. 2-5). Only data from the downcasts were used.

On this cruise, we also attempted to obtain bottom sediment samples using a HAPS corer (KC Denmark Research Equipment, Silkeborg, Denmark), with a total weight of about $140 \mathrm{~kg}$, and a core length and diameter of 30 and $14 \mathrm{~cm}$, respectively. This procedure was only successful at 12 out of the 16 stations because of the presence

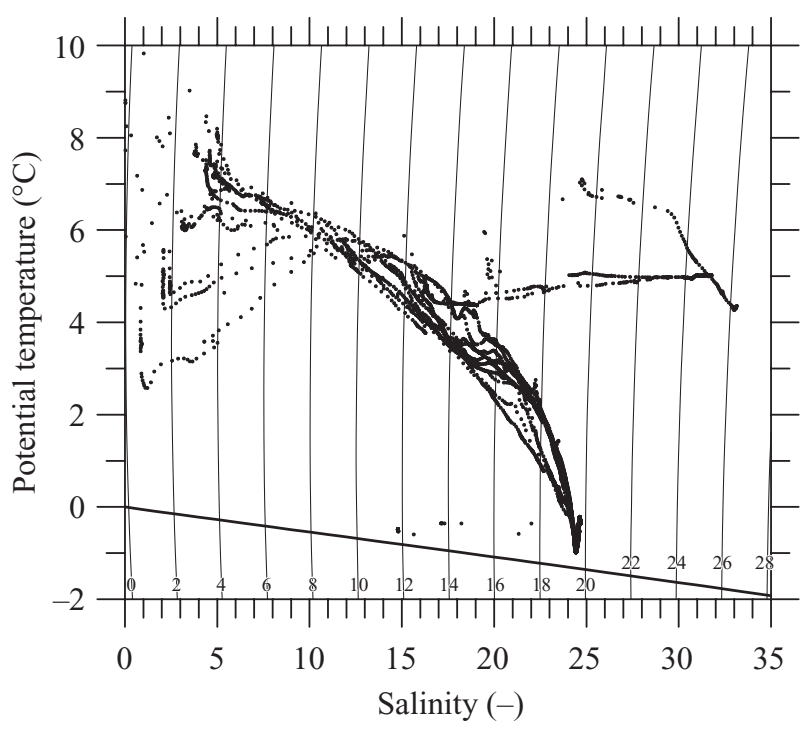

Fig. 3 Salinity-temperature plot of the data shown in Fig. 2. The thin lines are isolines (values as indicated) of the potential density minus $1000 \mathrm{~kg} \mathrm{~m}^{-3}$. The thick line indicates the freezing point. 
Fig. 4 Along-fjord distributions of (a) potential temperature and (b) salinity, measured on 26 and 27 February $2006(1 \mathrm{db}=\mathrm{ca} .1 \mathrm{~m})$. The values at the isolines are as indicated. The locations of the sampling sites are shown and marked as in Fig. 1. Note the direction of the plot (from north-east to south-west).

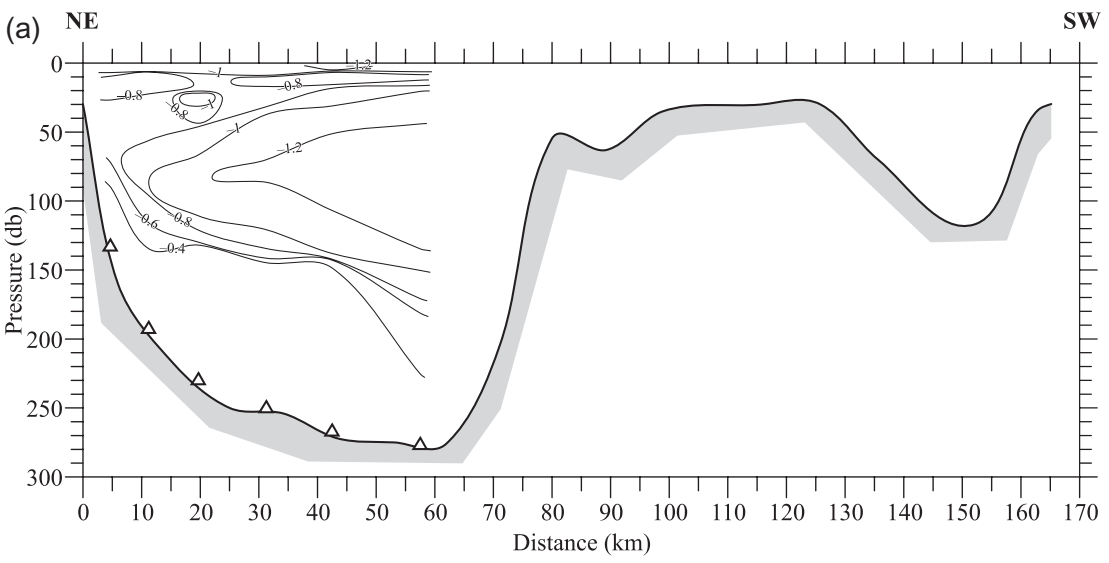

(b)

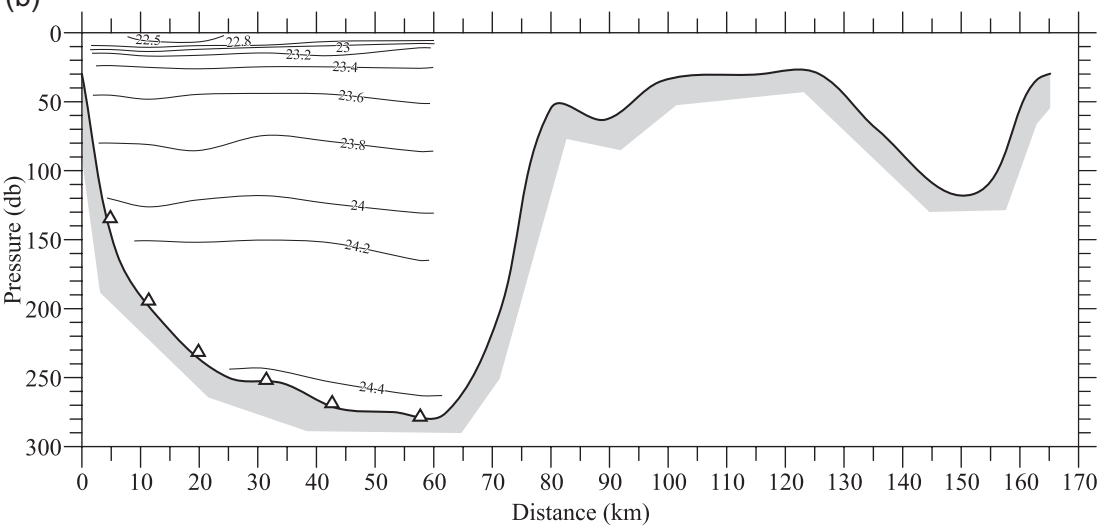

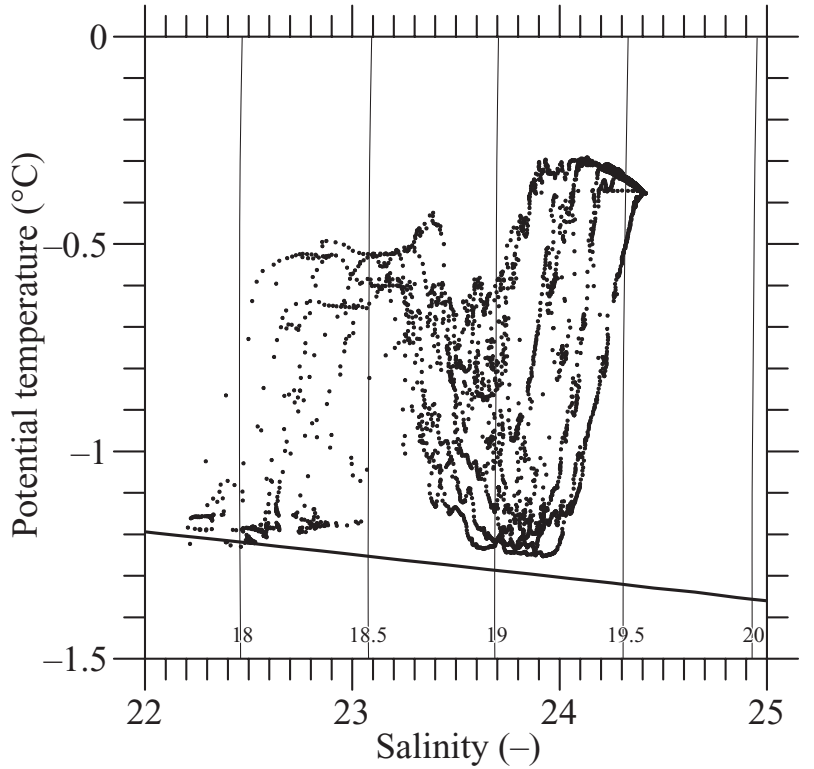

Fig. 5 Salinity-temperature plot of the data shown in Fig. 4. The thin lines are isolines (values as indicated) of the potential density minus $1000 \mathrm{~kg} \mathrm{~m}^{-3}$. The thick line indicates the freezing point. of coarse bottom sediments at some of the sites. Because of the difficulty in handling the HAPS corer in strong currents, the stations in the outer, narrow part of the fjord were visited around slack tide. Additionally, bottom sediment samples were obtained at a few shallow stations in the innermost part of the fjord using a small Van Veen grab (KC Denmark Research Equipment). In order to be able to study the quantity of living foraminifera compared with the number of empty tests, only the top layer (down to a maximum of $5 \mathrm{~cm}$ ) of the sediment was sampled and used for foraminiferal analysis. Most of the living foraminifera would occur in the top few centimetres of the sediment.

All the samples for foraminiferal analysis were immediately preserved in $60 \%$ ethanol (no buffer was added), and were subsequently stained with Rose Bengal on arrival at the Department of Earth Sciences, University of Aarhus, Denmark. The samples were processed a few weeks after collection. The reliability of the Rose Bengal staining technique to distinguish live from dead foraminifera has been reviewed by Murray \& Bowser (2000). As the majority of foraminifera die from predation or reproduction, most of the tests are left empty. Such shells would not occur as false "positives" in stained samples. In 
anoxic or hypoxic environments, dead individuals are more likely to be found containing protoplasm because of less, or maybe even absent, predation, and a relatively slow decay rate. As the sediments in Kangerlussuaq do not show any sign of anoxia or hypoxia, we regard the Rose Bengal technique as reliable for our study.

The samples for foraminiferal analysis were processed in accordance with the standard method described by Feyling-Hanssen et al. (1971) and Knudsen (1998). The volume of each sediment sample preserved in alcohol was measured before it was washed through sieves with mesh diameters of $0.063,0.1$ and $1.0 \mathrm{~mm}$. The different size fractions were subsequently dried at ca. $50^{\circ} \mathrm{C}$, and the foraminifera in the $0.1-1.0-\mathrm{mm}$ fraction were concentrated using tetrachlorethylen $\left(\mathrm{C}_{2} \mathrm{Cl}_{4}\right)$ with a specific gravity of $1.62 \mathrm{~g} \mathrm{~cm}^{-3}$.

The foraminiferal assemblages were analysed in the $0.1-1.0-\mathrm{mm}$ fraction by counting at least 300 specimens of each of the four following benthic groups, where possible: calcareous stained, calcareous unstained, agglutinated stained and agglutinated unstained tests. This, however, was only possible for two samples. All the available sediment material has been processed and analysed for each of the remaining samples (Tables 1, 2). A specimen was defined as living when at least one chamber was evenly stained.

Our preparation method differs from that of, e.g., Lloyd (2006a, b), who counted the $63-\mu \mathrm{m}$ fraction of his foraminiferal assemblages from wet samples in order to avoid destroying the fragile agglutinated tests. Our samples were not dried before washing either, whereas the fraction $0.1-1.0 \mathrm{~mm}$ was dried before counting. There is, however, no indication of any disintegration or loss of agglutinated tests in our samples. The differences in preparation methods could cause minor dissimilarities in the abundance of particularly the small and/or fragile agglutinated taxa, but we assume these to be insignificant for our qualitative comparisons.

A brief overview of the foraminiferal distribution was obtained, even though the counted number of foraminifera was generally low, and the uncertainty was accordingly high. A total of 53 taxa were identified: 29 calcareous and 21 agglutinated (Tables 1, 2). Because of the low numbers of foraminifera in most of the samples, only a limited statistical treatment of the data has been applied. For the specimen-rich samples, the percentage of each species (stained + unstained) is calculated in relation to the total assemblage (TA: calcareous stained and unstained as well as agglutinated stained and unstained tests), and is presented as histograms for selected species in Fig. 6, together with the percentage of stained (living) tests of each species (stained + unstained). For the percentage calculations, a minimum of 30 specimens (stained + unstained) were used. The number of specimens per $100 \mathrm{ml}$ of sediment is also indicated (Fig. 6, Table 2). The total counts of all the observed taxa are shown in Tables 1 and 2. The samples have been divided into four assemblage zones based on species compositions.

The February survey took place on the ice-covered part of the fjord, which includes only the inner, deep part. At six stations, distributed almost evenly throughout this area, holes were cut in the ice cover (up to $80 \mathrm{~cm}$ thick), and CTD profiles were made using the same instrument as described above. As a result of the cold air, part of the pump and hose system of the CTD froze between deployments, and was thawed using hot water. No bottom samples were obtained during the February survey.

\section{Results}

\section{Physical oceanography}

The temperature and salinity data from the August cruise are shown in Fig. 2, presented as contour plots based on the 16 vertical CTD profiles. The contour lines were drawn by hand to avoid problems with large differences between the horizontal and vertical resolution. The inner part of the fjord appears to be strongly stratified, with the salinity increasing from close to zero at the surface to about 24 at the bottom, and with the temperature decreasing from above $7^{\circ} \mathrm{C}$ at the surface to $-0.9^{\circ} \mathrm{C}$ at intermediate depths. Through the outer part of the fjord, the salinity and temperature change gradually toward the values found in the coastal water masses, i.e., a salinity of about 32 and a temperature of about $5^{\circ} \mathrm{C}$. As one approaches the wide and deep inner part of the fjord, the tidal currents decrease and stratification develops.

Data from the August cruise are also illustrated in a salinity-temperature diagram (Fig. 3), together with lines of constant density and the freezing point. The density of the profile data used in Fig. 3 is roughly one observation per metre. In the present case, the water masses include primarily the coastal water (high salinity, intermediate temperature), the brackish surface layer (low salinity, intermediate to high temperature) and the deep layer in the inner part of the fjord (salinity around 24.5, low temperature). Notably, the large number of data points associated with the deep layer are located in a small area of the plot, with the salinity ranging from 24.2 to 24.7 and the temperature ranging from -0.9 to $-0.5^{\circ} \mathrm{C}$. This corresponds to an extremely narrow range of density, indicating that the deep layer is almost homogeneous below $80 \mathrm{~m}$.

Temperature and salinity observations from the February survey are shown in Fig. 4 (also see description for 
Table 1 List of calcareous foraminiferal species with original references and total counts. The dead/ unstained and living/stained (bold italics) counts of specimens for each calcareous taxon are given separately.

\begin{tabular}{|c|c|c|c|c|c|c|c|c|c|c|}
\hline \multirow[b]{2}{*}{ Stations } & \multicolumn{10}{|c|}{ Foraminiferal counts } \\
\hline & \multirow{2}{*}{$\frac{02-04}{-}$} & \multirow{2}{*}{$\frac{18}{159}$} & \multirow{2}{*}{$\frac{17}{218}$} & \multirow{2}{*}{$\frac{15}{254}$} & \multirow{2}{*}{$\frac{13}{275}$} & \multirow{2}{*}{$\frac{12}{276}$} & \multirow{2}{*}{$\frac{11}{200}$} & \multirow{2}{*}{$\frac{5}{32}$} & \multirow{2}{*}{$\frac{4}{50}$} & \multirow{2}{*}{$\frac{2}{34}$} \\
\hline Depth (m) & & & & & & & & & & \\
\hline Astrononion gallowayi & & & & & & & 65 & & 8 & 180 \\
\hline Loeblich \& Tappan, 1953 & & & & & & & 10 & & 8 & 184 \\
\hline Astrononion sp. & & & & & & & & & 2 & \\
\hline Bolivina pseudopunctata & & & & & & & & & & 1 \\
\hline Höglund, 1947 & & & & & & & & & & 5 \\
\hline Buccella frigida s.l. & & & & & & & 36 & & 6 & 25 \\
\hline (Cushman, 1922) & & & & & & & 34 & 1 & 2 & 5 \\
\hline Buccella sp. & & & & & & & 1 & & 1 & \\
\hline Cassidulina reniforme & & & & & & & 5 & & 1 & 27 \\
\hline Nørvang, 1945 & & & & & & & & & 1 & 13 \\
\hline Cibicides lobatulus & & & 1 & & & & 23 & & 52 & 59 \\
\hline (Walker \& Jacob, 1798) & & & & & & & 4 & & 6 & 23 \\
\hline \multicolumn{11}{|l|}{ Cornuspira planorbis } \\
\hline Scultze, 1854 & & & & & & & 1 & & 1 & \\
\hline Elphidiella arctica & & & & & & & & & 1 & \\
\hline \multicolumn{11}{|l|}{ (Parker \& Jones, 1864) } \\
\hline Elphidium albiumbilicatum & & & & & & & 39 & & 9 & 18 \\
\hline (Weiss, 1954) & & & & & & & 34 & & 4 & 6 \\
\hline $\begin{array}{l}\text { Elphidium excavatum } \\
\text { (Terquem) f. clavata }\end{array}$ & 1 & 24 & 2 & & 5 & & 167 & 1 & 2 & \\
\hline Cushman, 1930 & 1 & 14 & 2 & & 2 & & 222 & 1 & 3 & \\
\hline Elphidium hallandense & & & & & & & & & 1 & \\
\hline Brotzen, 1943 & & & & & & & 1 & & & \\
\hline Elphidium sp. & & & & & & & & & 1 & \\
\hline Eoeponidella pulchella & & & & & & & 1 & & & \\
\hline (Parker, 1952) & & & & & & & 1 & & & \\
\hline Haynesina nivea & & & & & & & & & & 1 \\
\hline \multicolumn{11}{|l|}{ (Lafrenz, 1963) } \\
\hline Miliolinella subrotunda & & & & & & & 1 & & & \\
\hline (Montagu, 1803) & & & & & & & 1 & & & \\
\hline Nonionellina labradorica & & & & & & & 1 & & & \\
\hline \multicolumn{11}{|l|}{ (Dawson, 1860) } \\
\hline \multicolumn{11}{|l|}{ Nonionellina sp. } \\
\hline \multicolumn{11}{|l|}{ Patellina corrugata } \\
\hline Williamson, 1858 & & & & & & & & & & 4 \\
\hline Quinqueloculina seminulum & & & & & & & 2 & & 10 & 2 \\
\hline (Linné, 1758) & & & & & & & 10 & & 4 & 1 \\
\hline Rosalina praegeri & & & & & & & & & & 1 \\
\hline (Heron-Allen \& Earland, 1913) & & & & & & & & & & 2 \\
\hline Rosalina cf. wrightii & & & & & & & & & & 1 \\
\hline (Brady, 1881) & & & & & & & & & & 1 \\
\hline Scutoloris tegminis & & & & & & & & & & \\
\hline (Loeblich \& Tappan, 1953) & & & & & & & 6 & & & \\
\hline Stainforthia loeblichi & & & & & & & & & & \\
\hline (Feyling-Hanssen, 1954) & & & & & & & & & & 11 \\
\hline Trifarina fluens & & & & & & & 1 & & & \\
\hline (Todd, 1947) & & & & & & & & & & 1 \\
\hline Unilocular & & & & & & & 3 & & 2 & 16 \\
\hline & & & & & & & 2 & & & 24 \\
\hline Indeterminate & & & & & & & 2 & 1 & & 1 \\
\hline
\end{tabular}


Table 2 List of agglutinated foraminiferal species with original references and total counts. The dead/unstained and living/stained (bold italics) counts of specimens for each agglutinated taxon are given separately. The total count per sample (stained and unstained calcareous tests plus stained and unstained agglutinated tests) and the total number of specimens per $100 \mathrm{ml}$ of sediment is indicated at the bottom.

\begin{tabular}{|c|c|c|c|c|c|c|c|c|c|c|}
\hline \multirow[b]{2}{*}{ Stations } & \multicolumn{10}{|c|}{ Foraminiferal counts } \\
\hline & \multirow{2}{*}{$\frac{02-04}{-}$} & \multirow{2}{*}{$\frac{18}{159}$} & \multirow{2}{*}{$\frac{17}{218}$} & \multirow{2}{*}{$\frac{15}{254}$} & \multirow{2}{*}{$\frac{13}{275}$} & \multirow{2}{*}{$\frac{12}{276}$} & \multirow{2}{*}{$\frac{11}{200}$} & \multirow{2}{*}{$\frac{5}{32}$} & \multirow{2}{*}{$\frac{4}{50}$} & \multirow{2}{*}{$\frac{2}{34}$} \\
\hline Depth (m) & & & & & & & & & & \\
\hline Adercotryma glomeratum & & & & & & & 4 & & & 6 \\
\hline (Brady, 1878) & & & & & & & 2 & & & 9 \\
\hline Ammodiscus sp. & & & & & & & & & & 1 \\
\hline \multicolumn{11}{|l|}{ Cribrostomoides crassimargo } \\
\hline (Norman, 1892) & & & & & & & & & & 4 \\
\hline Cribrostomoides jeffreysi & & & & & & & 5 & & & 3 \\
\hline (Williamson, 1858) & & & & & & & 3 & & & 1 \\
\hline Deuterammina montagui & & & & 3 & & & 10 & & & 5 \\
\hline Brönnimann \& Whittaker, 1988 & & & & & & & 12 & & & \\
\hline Deuterammina ochracea & & & & & & 2 & 10 & & & 9 \\
\hline (Williamson, 1858) & & & & & & & 5 & & 3 & 4 \\
\hline Eggerella advena & & & 1 & & & & 285 & 1 & 5 & 273 \\
\hline Cushman, 1922 & & & & & & & 238 & 1 & 23 & 264 \\
\hline Glaphyrammina americana & & & & & & & & & & 1 \\
\hline \multicolumn{11}{|l|}{ (Cushman, 1910) } \\
\hline Glomospira gordialis & & & & 24 & & & 2 & & & \\
\hline \multicolumn{11}{|l|}{ (Jones \& Parker, 1860) } \\
\hline Glomospira sp. & & & & & & & 1 & & & \\
\hline Paratrochammina bowlesensis & & & & & & & 8 & & 2 & 3 \\
\hline Brönnimann \& Whittaker, 1988 & & & & & & & 1 & & & \\
\hline Portatrocammina bipolaris & & & & & & & 1 & & & \\
\hline Brönnimann \& Whittaker, 1980 & & & & & & & 1 & & & \\
\hline Psammoshaera fusca & & & & & & & 2 & & & \\
\hline \multicolumn{11}{|l|}{ Schulze, 1875} \\
\hline Recurvoides turbinatus & & & & & & & 4 & & & 5 \\
\hline (Brady, 1881) & & & & & & & 3 & & & 4 \\
\hline Rhabdammina sp. & & & & & & & 1 & & & \\
\hline Reophax arctica & & & & & & & 1 & & & 5 \\
\hline \multicolumn{11}{|l|}{ Brady, 1881} \\
\hline Reophax fusiformis & & & & 24 & & & & & & \\
\hline (Williamson, 1878) & & & & 8 & & & & & & \\
\hline Reophax sp. & & & & & & & 3 & & & \\
\hline Saccammina difflugiformis & & & & 19 & & & & & & \\
\hline (Brady, 1879) & & & & 2 & & & & & & \\
\hline Spiroplectammina biformis & & & & & & & 11 & & & 10 \\
\hline (Parker \& Jones, 1865) & & & & & & & 2 & & & 10 \\
\hline Textularia sp. & & & & & & & & & & 1 \\
\hline \multicolumn{11}{|l|}{ Textularina torquata } \\
\hline Parker, 1952 & & & & & & & & & & 6 \\
\hline Trochammina sp. & & & & & & & 2 & & & \\
\hline $\begin{array}{l}\text { Turritellella shoneana } \\
\text { (Siddall, 1878) }\end{array}$ & & & & & & & & & & 1 \\
\hline Indeterminate & & & & 1 & & & & & & 15 \\
\hline & & & & & & & & & & 1 \\
\hline $\begin{array}{l}\text { Total count (stained and un-stained, } \\
\text { agglutinated plus calcareous) }\end{array}$ & 3 & 38 & 8 & 83 & 7 & 2 & 1287 & 6 & 160 & 1261 \\
\hline $\begin{array}{l}\text { Total per } 100 \mathrm{ml} \text { (stained and un-stained, } \\
\text { agglutinated plus calcareous) }\end{array}$ & 3 & 12 & 2 & 26 & 2 & 1 & 5400 & 60 & 100 & $1.5 \times 10^{7}$ \\
\hline
\end{tabular}


Fig. 2). The contour plots are based on vertical CTD profiles obtained at six locations on the ice-covered part of the fjord. At that time, the ice cover reached roughly the location of station KL11, from where the tidal currents apparently became too strong for ice to form. Contrary to the summer situation, the temperature and salinity show much smaller vertical gradients, with the temperature being low and the salinity being relatively high throughout the inner, deep part of the fjord. When plotted in a salinity-temperature diagram (Fig. 5; also see description for Fig. 3), the subtle differences between the water masses become apparent. Below a depth of roughly $125 \mathrm{~m}$, the fjord is occupied by a water mass of relatively high salinity (24.0-24.4) and relatively high temperature (from -0.3 to $-0.6^{\circ} \mathrm{C}$ ). This is the densest water in the fjord (Fig. 5). Above this, reaching up to a depth of about $30 \mathrm{~m}$, is a water mass that is extremely cold, with the temperature ranging from -1.0 to $-1.25^{\circ} \mathrm{C}$, and with a salinity from about 23.4 to 24.0 , which is close to the freezing point. More structure in the water masses is seen in the uppermost part of the water column. Between roughly 10 and $20 \mathrm{~m}$, there is a thin layer with a temperature from -0.5 to $-0.7^{\circ} \mathrm{C}$ and a salinity of $23.0-23.3$, which is well above the freezing point. Just below the ice, the conditions are close to freezing, with the temperature being about $-1.2^{\circ} \mathrm{C}$ and the salinity ranging from 22.3 to 23.0 . This water is only slightly lighter than the underlying layer.

\section{Foraminifera}

The samples from Kangerlussuaq have been divided into four assemblage zones (zones A-D) based on the foraminiferal contents (Fig. 6).

Zone A (samples KL02-04 and KL18) from the inner part of the fjord (Fig. 6) is largely affected by the meltwater from the inland ice. The samples are characterized by sparse foraminiferal contents. A monospecific calcareous assemblage of Elphidium excavatum forma clavata, with a high percentage of living specimens, occurs close to the Watson River outlet.

Most of the samples from zone B (KL17-12; Fig. 6) contain sparse assemblages, with only one being rich in foraminifera. Agglutinated species are totally dominant in this deepest part of the fjord (275 $\mathrm{m}$ depth). The most common species are Reophax fusiformis together with Glomospira gordialis and Saccammina difflugiformis, but only $R$. fusiformis and $S$. difflugiformis were observed to be living (Table 2). Among the few calcareous foraminifera found, a relatively large number were observed to be alive.

Sample KLll (zone C; Fig. 6) differs from the other inner fjord samples in that it has a much higher abundance of foraminifera. The sample derived from the transitional slope between the inner, deep part and the outer, shallow part of the fjord, at a water depth of $204 \mathrm{~m}$. The fauna has a slight dominance of calcareous species. In the calcareous portion of the fauna, the dominant taxon is E. excavatum f. clavata, followed by Astrononion gallowayi, Bucella frigida s.l. (mainly B. frigida forma calida Cushman \& Cole, 1930), Elphidium albiumbilicatum and Cibicides lobatulus. A high proportion of living specimens of $E$. excavatum f. clavata, B. frigida s.l. and E. albiumbilicatum was observed. The agglutinated part of the fauna is dominated by Eggerella advena, with Deuterammina ochracea, Deuterammina montagui and Spiroplectammina biformis as associated species. Few living specimens were found in the agglutinated fauna (Fig. 6).

Samples KL5, KL4 and KL2 are grouped in zone D, which is here extended to the edge of the slope (Fig. 6). Only a few samples were retrieved from this outer, shallow part of the fjord because of difficulties with sampling in coarse sediment and strong currents. The fauna is dominated by calcareous foraminifera with C. lobatulus, A. gallowayi and Quinqueloculina seminulum (Miliolida; Fig. 6) as the most abundant species. Three agglutinated species are observed, with E. advena being dominant. A total of $82 \%$ of E. advena were found to be alive at the time of sampling.

In order to obtain an indication of the faunal composition in an area dominated by coastal water, one of the samples was retrieved just outside the fjord outlet (KL2). This sample contains a mixed fauna with an equal dominance of the agglutinated and calcareous species groups, and with high species diversity and density. In the calcareous part of the fauna, A. gallowayi is dominant, followed by C. lobatulus, E. albiumbilicatum and B. frigida s.l. Among agglutinated species, E. advena is dominant, followed by $S$. biformis, D. montaguilochracea and several others. The percentage of living specimens is low in this sample, at only $1 \%$ (Fig. 6).

\section{Environmental interpretation}

\section{Physical oceanography}

In the inner, deep part of Kangerlussuaq, two water masses clearly stand out in the summer observations. These are the freshwater-influenced layer, occupying the upper 50-75 $\mathrm{m}$ of the water column, and the cold and relatively saline layer, occurring at depths below about $75 \mathrm{~m}$ (Fig. 2). The former is closely connected with the seasonal input of meltwater from the ice caps. On the other hand, the properties of the deep-lying water mass, i.e., a temperature from -0.9 to $-0.5^{\circ} \mathrm{C}$ and a salinity of about 24.5, which is close to the freezing point at surface pressure, suggest that this was formed in the wintertime, 


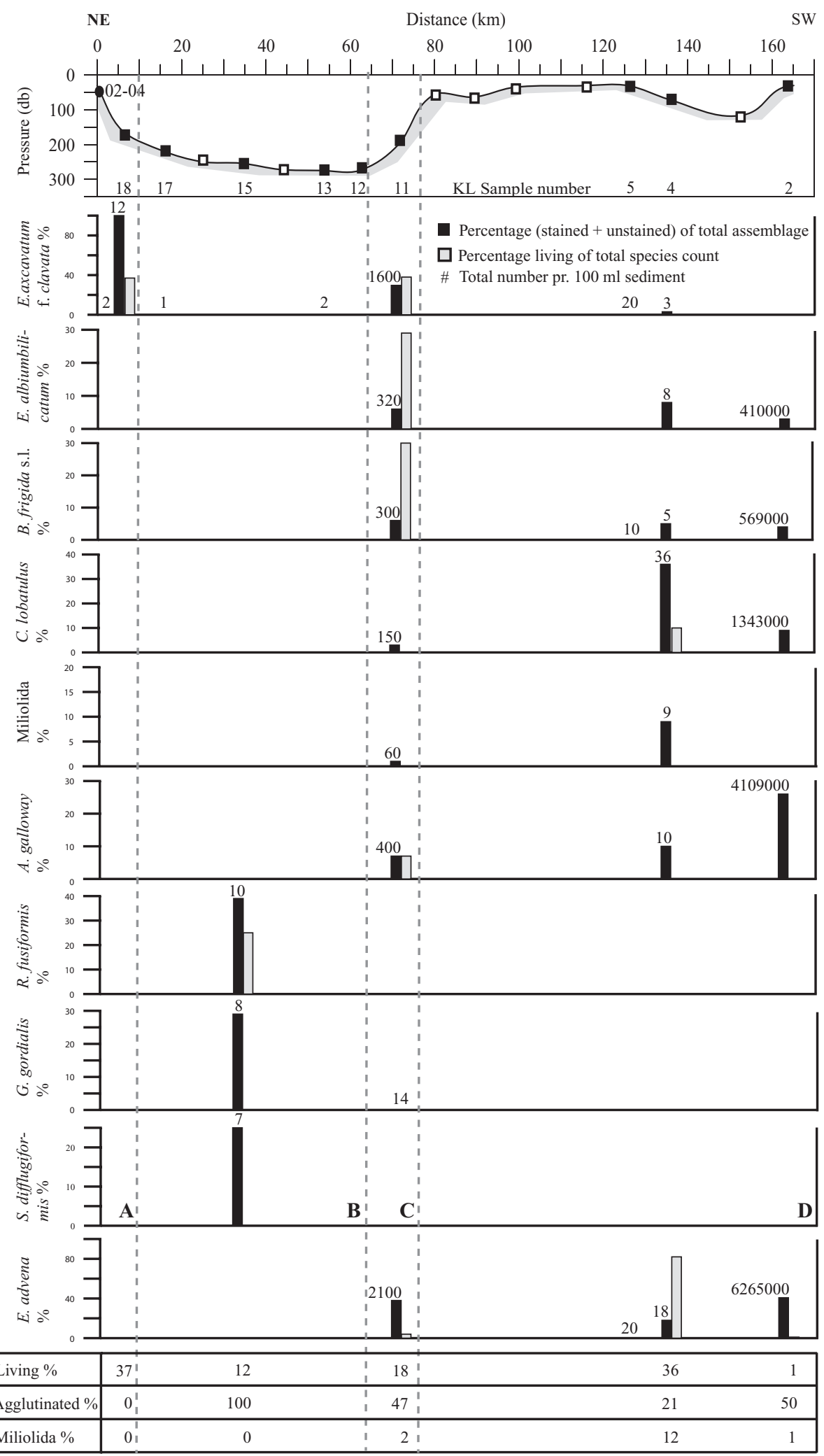


Fig. 6 Along-fjord percentage distribution of selected species (living plus dead) in relation to the total assemblage (living plus dead, calcareous as well as agglutinated) in Kangerlussuaq, shown as histograms, together with the percentage of living specimens in relation to the total species count (living plus dead). The total number of specimens per $100 \mathrm{ml}$ of sediment is also indicated. Symbols in the top part of the figure represent sampling locations ( $\mathbf{\square})$, three shallow sampling sites $(\mathbf{)}$ ) and conductivity-temperature-density stations from the August cruise without sediment sampling ( $\square$ ); see also Fig. 1. At the bottom of the diagram, the percentages of each of three foraminiferal groups (living, total agglutinated and total Miliolida) are shown. They are calculated in relation to total assemblages. Note the direction of the plot (from north-east to south-west).

in connection with strong cooling and the formation of ice. The latter process is associated with brine release and free convection, which may explain why the deep-lying water mass is almost homogeneous. We therefore assume that cooling and ice formation play a prominent role in shaping the physical oceanographic conditions in the fjord.

The gradual change of the density throughout the upper $50-75 \mathrm{~m}$ indicates that this layer is not subject to particularly strong wind mixing, and that the large, deeplying volume of cold, saline water is effectively sheltered from mixing from above. Additionally, in the present situation, the water masses that enter from the outer part of the fjord are actually less dense than the deep-lying water mass in the fjord, because of a strong, tidally driven mixing in the outer, shallow part. Large horizontal gradients and small vertical gradients, as found in the outer part of the fjord, are typical features of an estuary that is subject to intense mixing, in this case because of tidal flows (Fischer et al. 1979). The water mass along the coast of West Greenland, which has a summer temperature of about $5^{\circ} \mathrm{C}$ and a salinity of 33 , and is therefore relatively dense, is thus being considerably modified before it reaches the inner part of the fjord (see Fig. 3). From the situation shown in Fig. 2, we speculate that the deep-lying layer in the inner part of the fjord is hardly subject to any renewal during the summer, and that new water masses can only be added during the period of cooling and ice formation in the wintertime. We further note that in the depth range from about 20 to $75 \mathrm{~m}$, there is a large body of water with salinity ranging from 15 to 24 , with a temperature ranging from 4 to $0^{\circ} \mathrm{C}$, which is less dense than the deep-lying water, but which is much denser than the surface water. It may be that this intermediate water was created earlier in the summer, when the outflow of freshwater was smaller.

The winter survey was carried out in order to investigate whether the deep-lying water mass in the inner part of the fjord was created during the wintertime, and, if so, to study the resulting environmental conditions. Throughout the entire water column, we found water masses of properties close to the surface freezing point (Figs. 4, 5). This observation shows that cooling and ice formation are indeed the primary physical processes in wintertime. Furthermore, the subtle differences that are apparent from Fig. 5 shed some light on the conditions under the ice, suggesting that the different water masses have been created by different processes. The two extremely cold water masses, located just below the ice and at depths between 125 and $30 \mathrm{~m}$, seem to be a direct result of ice formation. On the other hand, the two water masses with temperatures somewhat above the freezing point, one of which is occupying the large volume below a depth of $125 \mathrm{~m}$, could have been formed by convective mixing as a result of brine release.

It is notable that the vertical gradients seem to be smaller at either end of the inner, deep part of the fjord (Figs. 2,4). In Fig. 5 these observations appear as a cloud of data points of temperatures from -0.6 to $-0.8^{\circ} \mathrm{C}$, and salinities between 23.4 and 23.8. A possible explanation is mixing caused by the propagation and breaking of internal waves, which could be created by the strong tidal currents in the outer, narrow part of the fjord (e.g., Arneborg \& Liljebladh 2001; Allen \& Simpson 2002). The undulations of the isolines seen in Fig. 2 at the transition between the two parts of the fjord support this hypothesis.

\section{Foraminifera}

The innermost part of the fjord, zone A, is characterized by a monospecific assemblage of E. excavaum f. clavata, which is indicative of ice-proximal environments. This taxon is, according to Hald et al. (1994), related to cold waters $\left(<1^{\circ} \mathrm{C}\right)$, variable or slightly reduced salinity, high sediment accumulation rates and soft substrata, and is common in Arctic fjords and shelf areas in association with these parameters (e.g., Elverhøi et al. 1980; Hansen \& Knudsen 1992; Hald et al. 1994; Korsun \& Hald 2000). The high percentage of living E. excavatum f. clavata in sample KL18 (37\%) may be indicative of a high sedimentation rate, resulting in fast burial of the dead tests, or it could be a result of carbonate dissolution (see Murray 1973). A high sedimentation rate is likely for the area because the meltwater entering the fjord close to the innermost sampling sites carries large quantities of sediment, as observed during the cruise and recorded by the CTD probe (data not shown). The calcareous foraminiferal tests in zone A do not show any sign of dissolution. 
The sparse agglutinated assemblages in the deepest part of the fjord, zone B, indicate an unfavourable environment for foraminifera, particularly for a calcareous fauna. The dominant species, $R$. fusiformis, is typical for relatively shallow areas in Arctic environments (Vilks 1969, 1989) as well as Atlantic-sourced environments (Vilks 1969, 1989; Lloyd 2006a). Vilks \& Deonarine (1988) found $R$. fusiformis within a wide range of salinity and temperatures $\left(30-35\right.$ and $0-4{ }^{\circ} \mathrm{C}$ ) on the Labrador Shelf, whereas Lloyd (2006a) regards $R$. fusiformis as an indicator of Atlantic Water. Jennings \& Helgadóttir (1994) recorded this species (as R. subfusiformis Earland, 1933) together with $S$. difflugiformis in three fjords and adjoining shelf areas in East Greenland, related to both Atlantic Intermediate Water (warm, high salinity) and Polar Water (cold, low salinity). The other common species, G. gordialis, was found together with $S$. difflugiformis in agglutinated assemblages dominated by the genus Reophax in Scoresby Sund Fjord (Madsen \& Knudsen 1994). In that area, these taxa were found at a much shallower water depth than in Kangerlussuaq, and were associated with Polar Water. Thus, it seems that $R$. fusiformis and $S$. difflugiformis are not only associated with Atlantic waters, as suggested by Lloyd (2006a), but they also occur in cold, low-salinity waters.

The assemblage characteristics in the deep part of Kangerlussuaq (zone B) indicate a hostile environment, possibly with carbonate dissolution. Agglutinated assemblages are often associated with Polar Water, and are related to permanent/semi-permanent ice cover (e.g., Wollenburg \& Mackensen 1998; Wollenburg et al. 2004) or to strong brine formation in enclosed basins (Seidenkrantz et al. 2007), where $\mathrm{CO}_{2}$ is brought to the sea floor as a result of freezing processes (Steinsund \& Hald 1994; Hald \& Steinsund 1996). Schröder-Adams et al. (1990) also reported that assemblages characterized by agglutinated foraminifera reflected increased sea-ice cover during periods of intensified atmospheric and surfacewater cooling.

The water mass in Kangerlussuaq has characteristics similar to Polar Water, i.e., low temperature and reduced salinity, and the CTD measurements indicate that the bottom waters in the inner, deep part of the fjord are almost decoupled from the ocean, and that renewal of the bottom water occurs as a consequence of brine release during winter, when the fjord is ice covered. Steinsund 8 Hald (1994) found that the mixing of Arctic and Atlantic waters, combined with seasonal ice cover, produces dense bottom water that is very cold and saline, and highly oxygenated. In Kangerlussuaq, however, the bottom water salinity is only 24.5 , which is relatively high compared with the rest of the fjord, but is low compared with the open ocean. The oxygen level has not been measured, but the sediment consists of grey clay/silt without any indications of low oxygen content. Steinsund $\&$ Hald (1994) found that dissolution of calcareous tests occurs at the sediment-water interface, when the decay of organic matter produces high concentrations of $\mathrm{CO}_{2}$. Thus, the calcareous component of the assemblages in the inner, deep part of Kangerlussuaq has possibly been exposed to carbonate dissolution, and assemblage zone B represents a residual assemblage of agglutinated foraminifera.

The calcareous part of the fauna in zone $\mathrm{C}$, from the transitional slope between the inner, deep and the outer, shallow parts, is typical for relatively stable salinity areas in Arctic marine environments. This is particularly indicated by the presence of A. gallowayi and B. frigida s.l. (cf. Haynes 1973; Hald \& Korsun 1997). The dominance of $E$. excavatum f. clavata, however, would indicate some influence of low-salinity waters in the area. The dominant agglutinated species, E. advena, is typical in Arctic waters, and is often associated with shallow water depth (Lloyd 2006a). This species is also tolerant to high contents of organic material and/or low oxygen concentrations, for example, in eutrophic areas (Barmawidjaja et al. 1995; Alve 1999; Tsujimoto et al. 2008). The agglutinated species D. montagui, D. ochracea and S. biformis are coldwater species (Brönnimann \& Whittaker 1988; Hald \& Korsun 1997), whereas Recurvoides turbinatus and Adercotryma glomeratum have been found to be associated with transformed Atlantic Water (Hald \& Korsun 1997; Lloyd 2006a).

The shift from an extremely sparse agglutinated assemblage in zone B to a specimen-rich and diverse fauna, slightly dominated by calcareous taxa, in zone C, suggests that the environmental conditions are different. The CTD measurements (Fig. 2), however, do not show any important difference between these sampling areas. The temperature and the salinity are similar in the two areas. This would indicate that other environmental parameters, e.g., the nutrient supply, are determining the faunal differences. As KLll is a shallower site with lower pressure, the water might be less corrosive to carbonate than in the deepest part of the fjord, even though the dominance of living calcareous foraminifera in KLll may indicate an under-representation of carbonate in the total assemblage at that site.

Additionally, station KLll is located where the fjord widens significantly, which causes the current speed of the incoming water to be reduced, as indicated by the change from coarse sediments in the outer, shallow part to clay sedimentation on the slope (zone $\mathrm{C}$ ) and in the inner, deep part of the fjord (zone B). It is also indicated by the change in the isolines, from diagonal to horizontal, as the incoming water becomes the surface layer in the inner, deep part of the fjord (Fig. 2). The abrupt reduction 
in current speed at the transition to the inner, deep part of the fjord would allow organic material to settle on the slope and create the basis for a rich foraminiferal community of species related to high organic contents, as evidenced by the dominance of E. advena, and by the increased density of foraminifera (5400 individuals per $100 \mathrm{ml}$ ). Large quantities of organic material, such as remnants of seaweed, as well as diatoms, ostracods and other crustaceans, were observed in the sample, but no measurements of organic contents are available. The foraminiferal faunal composition in zone $C$ is typical for an Arctic environment influenced by meltwater (e.g., Vilks $\delta$ Deonarine 1988; Jennings \& Helgadóttir 1994; Hald \& Korsun 1997; Lloyd 2006a).

The assemblage found in the outer, shallow part of the fjord, zone D, is typical for areas with relatively strong bottom water currents. The dominant species, C. lobatulus, is related to areas with high current velocities and coarse substrata, where it lives as an attached form on sand, pebbles or seaweed in normal marine or slightly reduced salinity (Haynes 1973; Jennings \& Helgadóttir 1994; Hald \& Korsun 1997). The low percentage of living C. lobatulus is probably a result of the habitat of this species, rather than an actual measure of the number of living specimens at the locality. Hald \& Korsun (1997) found a positive correlation between a low number of living C. lobatulus and a low sedimentation rate, which allows the accumulation of dead tests on the surface over several years. This interpretation is in accordance with the fact that the sea floor of the outer, shallow part of Kangerlussuaq is exposed to strong tidal currents, and that the sediment samples consist of sand and pebbles.

The high percentage of living E. advena in sample KL4 does not, however, fit with the indication of a low sedimentation rate, as interpreted from the low number of living C. lobatulus. A high post-mortem disintegration of the agglutinated tests because of the strong energy environment might explain this relatively high percentage of living specimens of E. advena. Sample KL4 is the only sample in the data set that contains a notable percentage of Miliolida, mainly Q. seminulum (12\%). Q. seminulum is a cosmopolitan species, which is most common in shallow waters with salinities around 33 (Murray 1991). Its presence in KLl1 indicates an influence from the open ocean into the outer, shallow part of the fjord, which is well supported by the hydrological data.

The general composition of the fauna outside of the fjord (KL2) is close to that found in zone C. However, E. excavatum $\mathrm{f}$. clavata is not present in KL2, the percentage of A. gallowayi is significantly higher, and the species diversity is higher than in zone $C$. This indicates that the environment is more like the normal marine environment, and less influenced by meltwater, outside the fjord than on the slope, as is also supported by the CTD data. The salinity at the mouth of the fjord is around 32, but is only 24.5 at the slope. The fauna at station KL2 also shows some similarity to faunal assemblage zone 6 (FAZ6) in Disko Bugt (Lloyd 2006a), which is characterized by shallow, relatively low-salinity waters (temperature $4.0^{\circ} \mathrm{C}$, salinity 33.27). The Disko Bugt assemblage has almost the same species distribution as sample KL2, but with the latter containing a relatively higher percentage of calcareous species.

The dominance of $A$. gallowayi and C. lobatulus, together with high numbers of Cassidulina reniforme, B. frigida s.l., Stainforthia loeblichi and unilocular species, in the calcareous fauna at KL2 (Table 1) indicates a relatively stable arctic marine environment (Hald \& Korsun 1997), and the influence of an oceanic component. The EGC component of WGC has a salinity around 32-33, corresponding to the measured salinity at station KL2. The temperature at KL2 is, however, significantly higher than "normal" EGC water (see Buch 2002). This might be a result of either mixing of the EGC component with the relatively warmer IC component of WGC water, or maybe seasonal surface water heating of the EGC component of the WGC.

\section{Discussion and future prospects}

Kangerlussuaq appears to be subjected to the typical external forcing of polar regions, which are characterized by large seasonal variations, i.e., strong cooling in the wintertime and large freshwater run-off in the summertime. For both winter and summer, this creates water masses in the fjord that are much different from those found along the coast, resulting in an exchange flow between the fjord and the ocean. In typical Arctic (or Antarctic) fjords, the connection to the ocean is constricted by a short, shallow sill, which allows for a relatively easy and fast exchange between the deep fjord basins and the ocean. Thus, cold and saline water masses created in a fjord in the wintertime, as a result of cooling and ice formation, may be replaced on a seasonal time scale, or often faster, as the coastal waters become denser and overflow the sill. Examples are given by Matthews (1981), Jennings \& Helgadóttir (1994), Niebauer et al. (1994), Madsen \& Knudsen (1994) and Skogseth et al. (2005).

However, in Kangerlussuaq the shallow and narrow outer part of the fjord is long (ca. $100 \mathrm{~km}$ ) compared with the tidal excursion (ca. $20 \mathrm{~km}$ ), and the tidal currents are strong, resulting in well-mixed conditions and weak gradients of the water-mass properties in both time and space. These circumstances cause a strongly dampened exchange between the water masses in the fjord and 
those along the coast. This condition is approaching the solution that Hogg et al. (2001) called the viscous advective diffusive, in which the transport of the water masses in opposite directions is determined by friction and the degree of vertical mixing. Given the magnitude of the seasonal forcing, we speculate that the large, deep-lying layer in the inner part of the fjord is subject to no or extremely slow renewal by coastal waters. Furthermore, the presence of the ice cover in the wintertime and the thick freshwater-influenced upper layer in the summertime effectively shelters the deep layer from upwardsdirected entrainment caused by turbulence created by wind stress, which would normally enhance estuarine exchange (e.g., Nielsen et al. 2005).

Our findings in Kangerlussuaq show a strong connection between the physical oceanographic conditions and the distribution of foraminifera. For instance, the deep part of the fjord (below about $200 \mathrm{~m}$ ) is typically inhabited by sparse agglutinated assemblages. On the other hand, the innermost, shallow part of the fjord is characterized by the high dominance of only one species, i.e., E. excavatum f. clavata, and a high proportion of living specimens. This fjord head is an area where finegrained sediment settles quickly, and according to local sources, sedimentation rates are up to several centimetres per year slightly north of sample KL18, possibly accounting for most of the sediment carried by Watson River.

The diversity of the foraminiferal assemblage on the transitional slope between the inner, deep part and the outer, shallow part of the fjord, reflects an influence of cold, low-salinity waters from the deep, homogeneous layer in the fjord, and the diversity and concentration of the foraminifera indicate that living conditions are generally favourable in this area, presumably because of the deposition of organic matter advected from the outer, shallow part and settling as the depth increases.

The foraminiferal assemblage in the outer, shallow part of the fjord is characterized by the dominance of the indicator species for strong bottom currents, C. lobatulus, as well as the relatively high-salinity species Q. seminulum. This is in accordance with the observation of pronounced tidal mixing and strong currents in this part of the fjord.

Off the mouth of Kangerlussuaq, we find a diverse foraminiferal assemblage related to the relatively stable Arctic conditions in the EGC component of the WGC. The water is, however, slightly warmer than the typical EGC, either because of mixing with the IC component of WGC waters or because of seasonal surface water heating. This area is also subject to moderate currents, as the tidal waves propagate northwards along the coast. The environment is typically inhabited by both calcareous and agglutinated species associated with Polar and Atlantic Water components of the WGC.

The present investigation leaves a number of questions open for future research. One question concerns the problem of the chemical conditions in the deep-lying water masses in the inner part of the fjord. Ice formation and brine release are associated with the downwards transport of oxygen and carbon dioxide (e.g., Steinsund $\delta$ Hald 1994; Rysgaard et al. 2007), and at increasing depth and decreasing temperature this may lead to carbonate dissolution and poor preservation of calcareous foraminifera. One way of assessing the impact of this process would be dense sampling of the surface sediments, combined with measurements of physical properties on the slope between the inner and the outer part of the fjord, and along the shoaling sides of the inner part of the fjord. At best, the chemical properties should also be measured directly.

Another question concerns the biological production in the fjord and the timing of the productivity. Sustained water-column stratification normally has a strong effect on the primary productivity, as would be expected to be the case here, by confining the upper part of the water masses to the photic zone, and by limiting the access to inorganic nutrients. However, the meltwater also carries large quantities of fine-grained sediment, and in suspension this may significantly constrict the availability of light. According to the physical forcing, we expect to find a strong seasonal variation in the fjord, and it may be that the primary production is limited to ice-free periods (see Rysgaard et al. 2003).

Finally, it is interesting that, because of the strong tidal mixing in the outer, shallow part of the fjord, the inner, deep part is largely decoupled from the oceanic conditions. Furthermore, the cooling and ice formation in the wintertime and the meltwater run-off in the summertime, which determine the conditions in the deep-lying water masses, are both direct results of the local meteorological conditions. We therefore expect that both the sediments and the foraminiferal contents in sedimentary records from the inner, deep part of Kangerlussuaq would hold unique information on the climate of West Greenland and its variations, at least through the Holocene. In addition, the well-defined water-mass properties in the fjord suggest that modelling of the physical oceanographic conditions may be straightforward, by employing the methods of, for example, Hogg et al. (2001) and Haarpaintner et al. (2001). For the study of climatic changes, modelling of variations in cooling and ice production in the wintertime and meltwater run-off in the summertime could become a valuable supplement to data from sediment cores. 


\section{Conclusions}

The study of a series of CTD profiles combined with analysis of the modern foraminiferal distribution in Kangerlussuaq (Søndre Strømfjord) shows that the occurrence of different foraminiferal species and species groups are related to physical water-mass characteristics at the sea floor as well as the availability of nutrients.

The physical oceanographic conditions in the fjord are much influenced by the strong seasonal forcing pertinent to the polar regions. For instance, in the summertime large quantities of meltwater run-off cause strong stratification, and in the wintertime cooling and ice formation lead to brine release and dense water formation. Importantly, because of the strong tidal mixing in the outer, shallow part of the fjord, the water mass of the inner, deep part of the fjord is almost decoupled from the oceanic conditions of the coastal waters. This implies that the conditions in the inner, deep part are determined primarily by cooling and ice formation in the wintertime, and by the meltwater run-off in the summertime, both direct results of local meteorological conditions.

Foraminiferal assemblages in the deep part of the inner basin are characterized by the sparse contents of agglutinated species, presumably determined by carbonate dissolution combined with the availability of nutrients. The innermost, shallow part, however, is inhabited by a glaciomarine assemblage dominated by the opportunistic form E. excavatum f. clavata, which tolerates sedimentloaded waters close to meltwater run-off from glaciers.

The foraminiferal assemblage found on the transitional slope between the outer, shallow part of the fjord and the inner, deep part indicates an Arctic environment with reduced salinity, as also recorded by the CTD measurements, and the relatively high foraminiferal density and species diversity may be a result of a steady supply of organic matter from the incoming waters to the slope.

The conditions in the outer, shallow part of the fjord are characterized by strong tidal mixing. The indicator species of strong bottom currents, C. lobatulus, and the relatively high-salinity group, Miliolida, are connected to this environment, which is under the influence of water with increased salinity from the more oceanic coastal area.

The association between the foraminiferal distribution in Kangerlussuaq and the water-mass characteristics, which are again coupled with the meteorological conditions, is promising for our future study of climate change in the area.

\section{Acknowledgements}

We thank the captain and crew of MS Suulut for their assistance on the August 2005 cruise, and Mr Bjarke
Tinghuus for his assistance on the survey on the ice in February 2006.

\section{References}

Allen G.L. \& Simpson J.H. 2002. The response of a strongly stratified fjord to energetic tidal forcing. Estuarine, Coastal and Shelf Science 55, 629-644.

Alve E. 1999. Colonization of new habitats by benthic foraminifera: a review. Earth-Science Reviews 46, 167-185.

Andersen O.G.N. 1981. The annual cycle of temperature, salinity, currents and water masses in Disko Bugt and adjacent waters, West Greenland. Meddelelser om Gronland, Bioscience 5. Copenhagen: Commission for Scientific Research in Greenland.

Arneborg L. \& Liljebladh B. 2001. The internal seiches in Gullmar Fjord. Part II: contribution to basin water mixing. Journal of Physical Oceanography 31, 2567-2574.

Barmawidjaja D.M., van der Zwaan G.J., Jorissen F.J. \& Puskaric S. 1995. 150 years of eutrophication in the northern Adriatic Sea: evidence from a benthic foraminiferal record. Marine Geology 122, 367-384.

Bennike O., Hansen K.B., Knudsen K.L., Penney D.N. \& Rasmussen K.L. 1994. Quaternary marine stratigraphy and geochronology in central West Greenland. Boreas 23, 194-215.

Brönnimann P. \& Whittaker J.E. 1988. The Trochammina of the Discovery reports. London: British Museum (Natural History).

Buch E. 2000. Air-sea-ice conditions off southwest Greenland, 1981-1997. Journal of the Northwest Atlantic Fisheries Sciences 26, 123-136.

Buch E. 2002. Present oceanographic conditions in Greenland waters. Danish Meteorological Institute Scientific Report 02-02. Copenhagen: Danish Meterological Institute.

Dowdeswell J.A., Whittington R.J., Jennings A.E., Andrews J.T., Mackensen A. \& Marienfeld P. 2000. An origin for laminated glacimarine sediments through sea-ice build-up and suppressed iceberg rafting. Sedimentology 47, 557-576.

Elverhøi A., Liestøl O. \& Nagy J. 1980. Glacial erosion, sedimentation and microfauna in the inner part of Kongsfjord, Spitsbergen. Norsk Polarinstitutt Skrifter 172, 33-61.

Feyling-Hanssen R.W. 1990. Foraminiferal stratigraphy in the Plio-Pleistocene Kap Kobenhavn Formation, North Greenland. Meddelelser om Gronland, Geoscience 24. Copenhagen: Commission for Scientific Research in Greenland.

Feyling-Hanssen R.W. \& Funder S. 1990. Fauna and flora. In S. Funder (ed.): Late Quaternary stratigraphy and glaciology in the Thule area, Northwest Greenland. Meddelelser om Gronland, Geoscience 22, 19-32.

Feyling-Hanssen R.W., Jørgensen J.A., Knudsen K.L. \& Lykke-Andersen A.-L. 1971. Late Quaternary foraminifera from Vendsyssel, Denmark and Sandnes, Norway. Bulletin of the Geological Society of Denmark 21, 67-367.

Fischer H.B., List E.J., Koh R.C.Y., Imberger J. \& Brooks N.H. 1979. Mixing in inland and coastal waters. New York: Academic Press. 
Haarpaintner J., Gascard J.-C. \& Haugan P.M. 2001. Ice production and brine formation in Storfjorden, Svalbard. Journal of Geophysical Research-Oceans 106, $14001-14013$.

Hald M. \& Korsun S. 1997. Distribution of modern benthic foraminifera from fjords of Svalbard, European Arctic. Journal of Foraminiferal Research 27, 101-122.

Hald M. \& Steinsund P.I. 1996. Benthic foraminifera and carbonat dissolution in the surface sediments of the Barents and Kara seas. In R. Stein et al. (eds.): Surface-sediment composition and sedimentary processes in the central Arctic Ocean and along the Eurasian Continental Margin. Berichte zur Polarforschung 212, 285-307.

Hald M., Steinsund P.I., Dokken T., Korsun S., Polyak L. \& Aspeli R. 1994. Recent and late Quarternary distribution of Elphidium excavatum f. clavata in Arctic seas. Cushman Foundation Special Publication 32, 141-153.

Hansen A. \& Knudsen K.L. 1992. Recent foraminifera in Freemansundet, eastern Svalbard. Lundqua Report 35, 177-189.

Hansen A. \& Knudsen K.L. 1995. Recent foraminiferal distribution in Freemansundet and Early Holocene stratigraphy on Edgeøya, Svalbard. Polar Research 14, 215-238.

Haynes J.R. 1973. Cardigan Bay recent foraminifera. Bulletin of the British Museum (Natural History) Zoology, Supplement 4. London: British Museum (Natural History).

Henriksen N., Higgins A.K., Kalsbeek F. \& Pulvertaft T.C.R. 2000. Greenland from Archaean to Quaternary. Descriptive text to the Geological map of Greenland, $1: 2500$ 000. Geology of Greenland Survey Bulletin 185. Copenhagen: Geological Survey of Denmark and Greenland.

Hogg A.M., Ivey G.N. \& Winters K.B. 2001. Hydraulics and mixing in controlled exchange flows. Journal of Geophysical Research-Oceans 106, 959-972.

Husum K. \& Hald M. 2004. Modern foraminiferal distribution in the subarctic Malangen fjord and adjoining shelf, northern Norway. Journal of Foraminiferal Research 34, 34-48.

Jennings A.E. \& Helgadóttir G. 1994. Foraminiferal assemblages from the fjords and shelf of eastern Greenland. Journal of Foraminiferal Research 24, 123-144.

Jennings A.E. \& Weiner N.J. 1996. Environmental change in eastern Greenland during the last 1300 years: evidence from foraminifera and lithofacies in Nansen Fjord, $68^{\circ} \mathrm{N}$. The Holocene 6, 179-191.

Kelly M., Funder S., Houmark-Nielsen M., Knudsen K.L., Kronborg C., Landvik J. \& Sorby L. 1999. Quaternary glacial and marine environmental history of northwest Greenland: a review and reappraisal. Quaternary Science Reviews 18, 373-392.

Knudsen K.L. 1998. Foraminiferer i Kvartær stratigrafi: laboratorie og fremstillingsteknik samt udvalgte eksempler. (Foraminifera in Quaternary stratigraphy: laboratory techniques and presentation as well as selected examples.) Geologisk Tidsskrift 3, 1-25.
Korsun S. \& Hald M. 1998. Modern benthic foraminifera off Novaya Zemlya tidewater glaciers, Russian Arctic. Arctic and Alpine Research 30, 61-77.

Korsun S. \& Hald M. 2000. Seasonal dynamics of benthic foraminifera in a glacially fed fjord of Svalbard, European Arctic. Journal of Foraminiferal Research 30, 251-271.

Lassen S.J., Kuijpers A., Kunzendorf H., Hoffmann-Wieck G., Mikkelsen N. \& Konradi P. 2004. Late-Holocene Atlantic bottom-water variability in Igaliku Fjord, south Greenland, reconstructed from foraminifera faunas. The Holocene 14, $165-171$

Lloyd J.M. 2006a. Modern distribution of benthic foraminifera from Disko Bugt, west Greenland. Journal of Foraminiferal Research 36, 315-331.

Lloyd J.M. 2006b. Late Holocene environmental changes in Disko Bugt, West Greenland: interaction between climate, ocean circulation and Jakobshavn Isbrae. Boreas 35, 35-49.

Lloyd J.M., Park L.A., Kuijpers A. \& Moros M. 2005. Early Holocene palaeoceanography and deglacial chronology of Disko Bugt, West Greenland. Quaternary Science Reviews 24, 1741-1755.

Madsen H.B. \& Knudsen K.L. 1994. Recent foraminifera in shelf sediments of the Scoresby Sund fjord, East Greenland. Boreas 23, 495-504.

Matthews J.B. 1981. The seasonal circulation of the Glacier Bay, Alaska fjord system. Estuarine, Coastal and Shelf Science 12, 679-700.

Møller H.S., Jensen K.G., Kuijpers A., Aagaard-Sørensen S., Seidenkrantz M.-S., Prins M., Endler R. \& Mikkelsen N. 2006. Late-Holocene environment and climatic changes in Ameralik Fjord, southwest Greenland: evidence from the sedimentary record. The Holocene 16, 685-695.

Mudie P.J., Keen C.E., Hardy I.A. \& Vilks G. 1983. Multivariate analysis and quantitative paleocology of benthic foraminifera in surface and Late Quaternary shelf sediments, northern Canada. Marine Micropaleontology 8, 283-313.

Murray J.W. 1973. Distribution and ecology of living benthic foraminiferids. London: Heinemann.

Murray J.W. 1991. Ecology and palaeoecology of benthic foraminifera. Harlow: Longman Scientific and Technical.

Murray J.W. 2006. Ecology and application of benthic foraminifera. Cambridge: Cambridge University Press.

Murray J.W. \& Bowser S.S. 2000. Mortality, protoplasm decay rate and reliability of staining technique to recognize "living foraminifera": a review. Journal of Foraminiferal Research 30, 66-70.

Niebauer H.J., Royer T.C. \& Weingartner T.J. 1994. Circulation of Prince William Sound, Alaska. Journal of Geophysical Research-Oceans 99, 14 113-14 126.

Nielsen M.H., Rasmussen B. \& Gertz F., 2005. A simple model for water level and stratification in Ringkøbing Fjord, a shallow, artificial estuary. Estuarine, Coastal and Shelf Science 63, 235-248.

Polyak L., Korsun S., Febo L.A., Stanovoy V., Khusid T., Hald M., Paulsen B.E. \& Lubinski D.J. 2002. Benthic foraminiferal assemblages from the southern Kara Sea, a 
river-influenced Arctic marine environment. Journal of Foraminiferal Research 32, 252-273.

Rysgaard S., Glud R.N., Sejr M.K., Bendtsen J. \& Christensen P.B. 2007. Inorganic carbon transport during sea ice growth and decay: a carbon pump in polar seas. Journal of Geophysical Research-Oceans 112, C03016, doi: 10.1029/ 2006JC003572.

Rysgaard S., Vang T., Stjernholm M., Rasmussen B., Windelin A. \& Kiilsholm S. 2003. Physical conditions, carbon transport, and climate change impacts in a northeast Greenland Fjord. Arctic, Antarctic, and Alpine Research 35, 301-312.

Schröder-Adams C.J., Cole F.E., Medioli F.S., Mudie P.J., Scott, D.B. \& Dobbin L. 1990. Recent Arctic shelf foraminifera: seasonally ice covered vs. perennially ice covered areas. Journal of Foraminiferal Research 20, 8-36.

Scott D.B., Schafer C.T. \& Medioli F.S. 1980. Eastern Canadian estuarine foraminifera: a framework for comparison. Journal of Foraminiferal Research 10, 205-234.

Seidenkrantz M.-S., Aagaard-Sørensen S., Møller H.S., Kuijpers A., Jensen K.G. \& Kunzendorf H. 2007: Hydrography and climate change during the last 4,400 years in Ameralik Fjord, SW Greenland-implications for Labrador Sea palaeoceanography. The Holocene 17, 1-15.

Skogseth R., Haugan P.M. \& Jakobsson M. 2005. Watermass transformations in Storfjorden. Continental Shelf Research 25, 667-695.

Steinsund P.I. \& Hald M. 1994. Recent calcium carbonate dissolution in the Barents Sea: paleoceanographic applications. Marine Geology 117, 303-316.

Tsujimoto A., Yasuhara M., Nomura R., Yamazaki H., Sampei Y. Hirose K. \& Yoshokawa S. 2008. Development of modern benthic ecosystems in eutrophic coastal oceans: the foraminiferal record over the last 200 years, Osaka Bay, Japan. Marine Micropaleontology 69, 225-239.

UNESCO (United Nations Educational, Scientific and Cultural Organization) 1981. International oceanographic tables. Vol. 3. UNESCO Technical Papers in Marine Science 39. Paris: UNESCO.

Vilks G. 1969. Recent foraminifera in the Canadian Arctic. Micropaleontology 15, 35-60.

Vilks G. 1989. Ecology of recent foraminifera on the Canadian continental shelf of the Arctic Ocean. In Y. Herman (ed.): The Arctic seas, climatology, oceanography, geology, and biology. Pp. 497-569. New York: Van Nostrand Reinhold Company.

Vilks G. \& Deonarine B. 1988. Labrador shelf benthic foraminifera and stable oxygen isotopes of Cibicides lobatulus related to the Labrador Current. Canadian Journal of Earth Sciences 25, 1240-1255.

Vosgerau H., Funder S., Kelly M., Knudsen K.L., Kronborg C., Madsen H.B. \& Sejrup H.-P. 1994: Palaeoenvironment and changes in the relative sea level during the last interglacial, Langelandselv area, Jameson Land, East Greenland. Boreas 23, 398-411.

Wollenburg J.E., Knies J. \& Mackensen A. 2004. High-resolution paleoproductivity fluctuations during the past $24 \mathrm{kyr}$ as indicated by benthic foraminifera in the marginal Arctic Ocean. Palaeogeography, Palaeoclimatology, Palaeoecology 204, 209-238.

Wollenburg J.E. \& Mackensen A. 1998. Living benthic foraminifera from the central Arctic Ocean: faunal composition, standing stock and diversity. Marine Micropaleontology 34, 153-185. 